\title{
Conflict Analysis of Sudimoro Village Pilkades in 2020 Regarding Money Politics
}

\author{
Mohammad Fajrul Falah ${ }^{*}$, Agus Machfud Fauzi² \\ ${ }^{1,2}$ Universitas Negeri Surabaya \\ *Corresponding Author. Email: Mohammad.18017@mhs.unesa.ac.id
}

\begin{abstract}
The existence of a village head election which is a 5-year agenda in a village other than as a form of a democratic party is also a new hope and motivation for the village community. Therefore, the enthusiasm of the community to participate in the democratic party performance is expected to be large and the community can channel their voting rights according to their respective consciences in order to create a clean and honest general election. The purpose of this study is to identify and analyze the conflicts that occurred in the Pilkades in Sudimoro village due to the practice of money politics. The research method used in this study is a qualitative method by conducting interviews and observations or observations, then for the theory the researcher uses the conflict theory of Lewis Coser. The reason the researcher uses the theory is because according to the researcher, the theory fits the phenomenon of the problem being studied. The results obtained after research on conflicts that occurred in the Pilkades have become a natural thing as a form of competition to be the best in order to be elected by the community, this view is based on experience in various general election events that have been carried out where there are always conflicts or disputes that occur. between residents who have different candidates for choice. The general election should be carried out as well as possible without any cheating on the part of the candidate, in order to produce a leader who is trustworthy and responsible.
\end{abstract}

Keywords: General election, village head, money politics, conflict

\section{INTRODUCTION}

The general election, which is on the 5yearly agenda or what the majority of people call a democratic party, really attracts the attention of all people. Including general elections in rural areas or village head elections always presents a phenomenon. the dynamics and even conflict of its own every time the election is held. The election of the village head is very interesting because from the performance or event the fate of the village in the future is determined, meaning that whether or not the village advances can be seen from the election of the village head candidate. The village head as the leader of the village government has the right and obligation to lead the village and from the village head various policies related to the village community are created. 
One of the objectives of holding village head elections is so that village communities can channel their voting rights properly according to their respective consciences. will produce an elected village head who is in accordance with the expectations of the village community.

Candidates for village heads are expected to have qualified and capable capabilities to later be able to lead the village well, the village community certainly really hopes that the village head who leads the village government can make a big contribution to the progress of the village and can serve all village community complaints well. For prospective village heads what must be done is to prepare himself so that later he can provide good and optimal service quality to the village community. Because this will automatically make the village community confident and ultimately vote, not by cheating, such as committing unlawful acts and being prohibited from general elections with money politics.

Money politics is a phenomenon that often occurs when there are general election events or performances at the government level Central (president) to lower levels (village head). The forms of money politics can be said to be very diverse, some are in the form of distributing $t$ shirts, basic necessities and even direct cash.[1], [2]

Based on five similar journals discussing conflicts in general elections due to money politics, it is explained that many people do not agree with the existence of money politics because they are considered to have a negative influence on development development in an area and also see that money politics is a crime that disguised and is one of the social diseases of the community that results in the destruction of community traditions and culture and can even damage the mentality of the nation to be slumped due to the influence of In view of that money politics can be considered a criminal act because it is considered a violation of the law, especially in Law number 10 of 2016 concerning regional elections in article 187 paragraphs 1 and 2[3]. The election of a village head, which is an arena for political contestation, is always a performance in which various interests of individuals and groups are ridden, and it is not uncommon for actions to be called criminal because of coercion, threats and physical violence. Apart from money politics and some of the actions mentioned above above, there are also other actions that are often encountered in general elections, for example before the start in terms of campaigns. In general, people consider this to be a normal thing and even accept money politics by candidates due to lack of knowledge due to the low quality of their education.

In this study, the formulation of the problem is how the form of the conflict in the Pilkades Sudimoro village in 2020 is related to money politics. So the purpose of this study is to try to analyze the form of conflict that occurred in the village head election due to money politics behavior in Sudimoro village in 2020. Researchers are interested in researching this because they are interested in analyzing more deeply the conflict that occurred in the village head election in Sudimoro due to the existence of money politics behavior. On the night before the $\mathrm{D}$ day of the village head election, the situation in Sudimoro village can be said to be very tense even though at first glance it looks quiet,

Village head election in the law it is explained that it is one of the democratic arenas in which the people or residents in a village can channel their voting rights to determine the pair of candidates who will later serve as village heads.[4] including residents of Indonesian citizens, 
devoted to God Almighty, at least 25 years old and at least junior high school education or equivalent, etc [5].

The practice of money politics according to Juliansyah (2007) is an action taken to buy votes from the people, the practice of money politics is actually an act that violates the law because it is considered a fraud. The practice of money politics is considered to violate the general election principle consisting of LUBER and JURDIL, residents or citizens have the right to vote directly, publicly, freely, confidentially and honestly and fairly. The purpose of the existence of this principle is so that people can freely channel their voting rights according to their beliefs and conscience.

While the definition of conflict [6] according to Robbins is a actions that have a negative impact on opponents or parties who have different interests. So in a conflict the competing parties try to bring each other down to realize their respective goals.

The research method used in this study is a qualitative method with descriptive analysis in order to explain in detail the various information or data that have been collected previously. The approach taken in this study uses in-depth interview techniques accompanied by observations or observations in order to adjust and evaluate various data or information that has been obtained previously so that in this research later it can be objective and concrete in accordance with the realities that exist in life[7].The reason the researcher uses these methods and approaches is because they are considered very suitable for digging in-depth information through the informants, namely the residents of the Sudimoro village. Then for the theory, the researcher uses the conflict theory from Lewis Coser in which it is explained that conflict functions as a process of formation, unification and maintenance. existing social structure [8]. The reason the researcher uses the theory is because according to the researcher, the theory fits the phenomenon of the problem being studied.

If it is related to the problem that is the focus of the study, namely analyzing the conflict in the village head election in Sudimoro village in 2020 related to money politics, the researcher sees that the conflict that occurs certainly cannot be separated or is still related to differences in choices or beliefs to choose a candidate pair in the community. between the support groups and the success team of the village head candidates, but if viewed broadly, no matter how big the conflict is, the conflict will surely be extinguished if all parties and groups can accept it well and with an open heart whoever the candidate is elected to be the village head. in Sudimoro. Even though it is certain that in the process there are always parties who are dissatisfied with the results that have emerged or been determined.Based on this, the social structure can run normally again as before.

\section{METHODS}

This study uses a qualitative method. Maanen (1979: 520) describes the qualitative method as a technique for interpreting phenomena in the social world. The approach used in this research is Schutz phenomenology.

Data collection techniques using interviews, observation, and documentation. The interview process uses unstructured interviews. Unstructured interviews do not prioritize question instruments, but are spontaneous during data collection while still directing the topic of study (Sugiyono, 2010: 233). In the implementation of observations using active participant observation which makes the researcher blend with the research 
subject (Sugiyono, 2015: 329). Documentation is oriented to the personal records of the informants. Selection of informants using purposive technique. Therefore, informants already have criteria in selecting informants so that the data obtained can be intact and integrated

Analysis of the data using analytical techniques from Miles and Huberman. The analysis process includes data reduction, data presentation, and conclusion drawing [9]. So the first operational sequence after collecting data from the field, the researcher performs data reduction, namely classifying, simplifying data and removing unnecessary data. This is intended, because not all data collected in the field is relevant to the topic of discussion [10]. Presentation of data in the form of narrative. Then, in the conclusion stage looking for the essence of the research.

\section{RESULTS AND DISCUSSION}

Indonesia is a country that adheres to a democratic government system in which the people are the holders of the greatest power, therefore there is often a statement that the system of government is from the people by the people and for the people [11].

Leaders come from the people, are elected by the people and have power to provide welfare to the people. This can be reflected when there are democratic party performances in the form of popular elections, the voting rights of the people have a major contribution in determining leaders for the future.

The implementation of democracy that is happening today can be said to have good results or impacts compared to when it adheres to the royal system, because when Indonesia adheres to the system of the kingdom or the highest power is in the hands of the people's government as helpless because the power is authoritarian, the government is free to freely make a policy without regard to the welfare or fate of its people[12].

When Indonesia adopts a royal government system or an authoritarian leader in power, nepotism is very widespread in which only family or personal interests are concerned. The pillars of government power can be controlled by themselves according to their personal wishes.

Therefore, now as a good citizen what must be done is to be grateful for the government system that has turned into a democracy where the highest power is in the hands of the people and now the fate of the people in government is the main priority. can continue to run well, and as citizens have an obligation to guard the government through the policies taken.

Democracy is the best system of government in the world because in it the people can participate in government because the people are the holders of the highest power. Therefore, there needs to be a good synergy or cooperation between the government as the holder of power and the policy makers and the people as the parties who participate as policy guards so that Indonesia becomes an advanced nation and its people can live prosperously and prosperously.

The village head election in Sudimoro was actually held at the end of 2020 to be exact in November, but due to the COVID-19 pandemic the implementation of the village head election was postponed. It turns out that the village head election in Sudimoro village was held in early 2021 to be exact in February. Based on the Minister of Home Affairs Regulation number 72 of 2020 explained that the implementation of the village head election still had to implement health protocol regulations, 
namely wearing masks, washing hands and maintaining distance.

In this study, the focus is more on analyzing and trying to understand the conflicts that occurred in the Pilkades in Sudimoro village. In the Pilkades in Sudimoro the conflicts that occurred and arose were caused by differences of opinion in terms of the choice of candidates. Among the 3 candidates who proposed to participate in the Pilkades actually had the power The three candidates for village head who volunteered were all men and had a fairly good success team because they also embraced several community leaders who were considered influential in Sudimoro. The strategy used was a problem because the three candidates both practiced money politics.

The candidates for the village head have their own voting base which is near the house of the candidate for the village head the success team that spreads throughout the village has their respective duties and roles in recruiting votes in order to achieve the goal of the candidate for village head to win the village head election and to be elected as village head.

From the results of research conducted on the conflict analysis of the Sudimoro Village Pilkades in 2020, researchers got a lot of information data related to the problems being studied. chosen, because every member of the community in Sudimoro village certainly has a choice based on their respective beliefs. The researcher also saw the conflict between the success teams of the three pairs of candidates, although the conflict did not result in physical violence, the conflict that occurred could be said to be very internal in every citizen. Because on the night before the election day for the village head in every alley or area it seemed very hot because they were guarding each other's voices from the community.

Therefore, although it is normal for differences of opinion to occur in terms of belief in choosing a candidate pair, seeing the conflict that occurs is not only because of differences of opinion but is more interested in the practice of money politics. each pair of candidates through their success team guerrillas to buy the votes of the residents of Sudimoro village, the methods used are also varied, some are distributing cash, basic necessities or t-shirts.

After conducting the research, the researchers also received information that in fact many residents were afraid and confused because of the success of the guard that was carried out by ti every candidate in order to maintain their vote, as a result, residents feel they cannot be free and free to travel because they will definitely be asked about the intent and purpose of leaving. Because of this, researchers are interested in researching this phenomenon, because the practice of money politics is actually against the law and is considered fraudulent.

Money politics is like a culture that is carried out by every candidate who runs as a leader or official, it cannot be denied that every time there is a general election from the village level to the center there must be someone who practices money politics.

Legally, money politics is illegal to do because it can be considered fraudulent and also violates the actual principles of elections, namely LUBER and JURDIL, where the people as determinants are given the freedom to determine their voting rights based on their beliefs and conscience. determine and distribute their voting rights freely, honestly and fairly, because if there is 
a money politics practice, of course there are those who ride it either because of personal interests or group interests. [13].

Because the practice of money politics in general elections also violates the election principle consisting of LUBER and JURDIL, where the community actually has the right to conduct direct, free, secret and honest and fair elections. Money politics culture should be minimized if every citizen has knowledge politics and proper and adequate education.

If the culture of money politics is still carried out and running every time there is a general election, of course it will later become a bad cultural heritage for the nation's children and grandchildren.Of course, those who give and receive can be punished or subject to sanctions.

In this study, the researchers collected data and information based on the experiences of the community members in Sudimoro village, because the Pilkades in Sudimoro village was held last January with three candidates as village head candidates.

The approach chosen in this study, the researchers conducted interviews and in-depth observations on the residents of the Sudimoro village. The researchers selected 15 informants who were considered capable of providing useful information in this study. [7]The details of the informants that have been determined by the voters include 5 informants who are considered important figures in the community and then the other ten informants are ordinary residents of Sudimoro village.

The researcher analyzes and tries to understand the conflicts that occurred in the Pilkades of Sudimoro village by using the perspective of conflict theory put forward by Lewis Coser, in his view conflict is considered as a process of unifying, forming and maintaining social structures. [14].

From the perspective of the theory proposed by Coser, it can be understood that a conflict cannot always be interpreted as a negative thing, because it turns out that conflict can also be seen as a positive thing and in this theory there is a way called a rescue valve.

According to Coser, a conflict can maintain a social structure, if it is related to the phenomenon of the problem being studied Regarding the conflict that occurred in the Pilkades of Sudimoro village, it can be seen that even before the time for the Pilkades to be held, there were conflicts in the community due to differences in choices, but in the end, during the Pilkades or after the results came out and a new village head appeared, of course, the community would return to normal although it cannot be denied that there are people who are dissatisfied with the results. However, as good citizens, of course, they must be able to accept gracefully whatever results have been decided and must respect the village head who has been elected by participating in implementing various policies taken or determined further.

Below are the rules that discuss the election of village heads as well as appeals or recommendations so that in the administration of the state or government to avoid corruption, collusion and nepotism.

The following are the basic rules regarding the implementation of village head elections: 


\section{Constitution}

Law NO. 6 OF 2014 Article 31 paragraph 3, regarding procedures for simultaneous village head elections

PERMENDAGRI NO. 65 of 2017 concerning the election of village heads

PERMENDAGRI NO.66 of 2017 concerning the appointment and dismissal

Law NO. 28 of 1999 concerning state administration that is clean and free from corruption, collusion and nepotism

From the chart above, it can be concluded that the implementation of village head elections has been regulated in detail with the hope that in its implementation can fulfill the procedures as stipulated and so that in the village head election there is no fraud in any form including the practice of money politics. Because the hope of holding a general election is to produce competent leaders who can later contribute greatly to development,

\section{CONCLUSION}

The existence of village head elections which are included in the democratic party performances can always cause conflicts both internally and externally. In the Pilkades in Sudimoro village it can be seen that there are many conflicts and indeed these conflicts arise due to differences in interests in terms of candidate selection. candidates have their own strategies to be elected as village heads in Sudimoro, through their success team the candidates try to win votes from the community. However, there is still a game of money politics in it, even though the action is legally included in a criminal act because it is essentially the same just like corruption.Conflicts that occur in the community can indeed be said to be internal or invisible, but when analyzed in depth based on observations of the resulting conflict, it really makes people feel afraid because the atmosphere is very tense. money, groceries or tshirts, even in narrow alleys, are already there to keep people's voices safe from the influence of other candidates.even in narrow alleys there are already safeguards so that people's voices are safe from the influence of other candidates.even in narrow alleys there are already safeguards so that people's voices are safe from the influence of other candidates.According to Lewis Coser, conflicts that occur can be resolved properly if there is a rescue valve, meaning that even though the village head has been elected, there must be people who feel they are not satisfied with the results. So it can be concluded that the conflict in the election of village heads in Sudimoro was caused by differences in interests and also the practice of money politics. The suggestion from the researcher himself is that in all general elections, the government must make good and strict procedures for bind the parties involved in it so that the general election can be carried out properly in accordance with the principles of LUBER and JURDIL.

\section{ACKNOWLEDGMENT}

This research can be carried out well and smoothly thanks to the help and support of various parties. For this reason, the researchers would like to thank and appreciate all levels of the Sudimoro village government who have been willing to provide some data and advice during the research, the Sudimoro village residents who have been willing to become informants in this research and to their parents who always provide motivation and support for the implementation of this research. so that the author can complete this research well without any problems or obstacles. 


\section{REFERENCES}

[1] S. A. Fauzi and A. M. Fauzi, "Fenomena Money Politik pada Pemilihan Kepala Desa Petiken Tahun 2018," vol. 23, p. 9, 2021.

[2] F. Rozy, P. A. Ramadhan, R. Febriansyah, F. A. Fahrurozi, A. I. Rizky, and A. M. Fauzi, "Praktik Politik Uang dalam Proses Pemilihan Kepala Desa Sumberingin Kidul Tahun 2019,' J. Socius J. Sociol. Res. Educ., vol. 7, no. 1, p. 37, Jun. 2020, doi: 10.24036/scs.v7i1.171.

[3] B. Muhtadi, "Politik Uang dan New Normal dalam Pemilu Paska-Orde Baru," Integritas J. Antikorupsi, vol. 5, no. 1, pp. 55-74, 2019.

[4] A. M. Fauzi, M. Mudzakir, and M. O. Abdulrahim, "Social Conflict In Contestation Of Indonesia Election," J. Soc. Media, vol. 3, no. 2, p. 159, Oct. 2019, doi: 10.26740/jsm.v3n2.p159-177.

[5] K. S. UPN Internasional, "PERSYARATAN CALON KEPALA DESA,” vol. 2, no. 1, pp. 73-80, 1945.

[6] D. D. Shoa and H. M. Gizaw, "Political Dynamics the Rift of EPRDF Coalitions Since the Outbreak of Qerro's Protest to the Nomination of Dr. Abiy Ahmed in Ethiopia," J. Soc. Media, vol. 5, no. 1, p. 1, Apr. 2021, doi: 10.26740/jsm.v5n1.p1-18.
[7] Suyitno, Metode Penelitian Kualitatif: Konsep, Prinsip, dan Operasionalnya. 2018.

[8] R. T. Sataloff, M. M. Johns, and K. M. Kost, "(Kajian Konflik Sosial Lewis A. Coser)," pp. $1-7$.

[9] I. M. L. M. Jaya, METODE PENELITIAN KUANTITATIF DAN KUALITATIF. Yogyakarta: Quadrant, 2020.

[10] J. W. Creswell, Reseacrh Design: Pendekatan Metode Kualitatif, Kuantitatif, dan Campuran, Keempat. Yogyakarta: Pustaka Pelajar, 2019.

[11]D. F. Ushuluddin, "NEGARA DEMOKRASI DAN HAK ASASI MANUSIA," J. Tapis, vol. Vol.7 No.1, 2011.

[12]I. P. A. Astawa and S. Pt, "DEMOKRASI INDONESIA,” Univ. Udayana, no. 13, 2017.

[13] P. J. Rimbing, "Politik Hukum Tindak Pidana Politik Uang dalam Pemilihan Umum di Indonesia," Integritas J. Anti Korupsi, vol. 5, no. 1, pp. 1-14, 2019.

[14] L. Dodi, "SENTIMENT IDEOLOGY: MEMBACA PEMIKIRAN LEWIS A. COSER DALAM TEORI FUNGSIONAL TENTANG KONFLIK (Konsekuensi Logis Dari Sebuah Interaksi di Antara Pihak Jamaah LDII Dengan Masyarakat Sekitar Gading Mangu-Perak-Jombang),' J. Al- 'Adl, vol. 10, no. 1, pp. 104-124, 2017. 